\title{
Learning Objects: An Expedition from Archival Collection to Online Collaboration
}

\author{
By Shu Liu ${ }^{1}$
}

\begin{abstract}
People of Chinese origin have lived in British Columbia, Canada, since the beginning of non-aboriginal settlement. Many of them have left Chinese-language records that are valuable for the study of Chinese immigrant history. This article provides information about a pilot project completed at the Asian Library of the University of British Columbia to build a learning-object repository using an archival collection of historical Chinese language materials. The collection supports the undergraduate curriculum Chinese-Canadian history. This article introduces the definition and characteristics of learning objects and learning-objects metadata resulting from the project's investigation and the author's experience with selecting and testing systems to develop a prototype of a learning-object repository.
\end{abstract}

Keywords: learning objects, learning-object metadata, learning-object system, Plone, CAREO, Chinese-Canadian history, archival collections, Historical Chinese Language Materials in British Columbia, HCLMBC, Asian Library, The University of British Columbia

\footnotetext{
${ }^{1}$ Shu Liu, M.L.I.S., Metadata Librarian, Digital and Collection Services, Colorado State University Libraries. Mailing address: Morgan Library, 1019 Campus Delivery, Colorado State University, Fort Collins, CO, 80523-1019. Email: shu.liu@colostate.edu. She was the primary investigator for the project described in the article when she worked as a graduate academic assistant at Asian Library, The University of British Columbia, 2003-2004. The author acknowledges Eleanor Yuen, Henry Yu, Phoebe Chow, for their participation in the project, and the HCLMBC team for providing information on the archival collection at their Web site to write relevant sections in the article.
} 
People of Chinese origin have lived in British Columbia, Canada, since the beginning of non-aboriginal settlement. Many have left behind manuscripts, newspapers, correspondence, genealogical and family records, business transaction records, association records, certificates, receipts, textbooks, photographs with captions, catalogues, and other documents in the Chinese language. ${ }^{1}$ These materials vividly reflect how Chinese immigrants have settled, struggled, grown, and thrived in a foreign land and are of significant value to the study of Chinese-immigrant history, migration to North America, and the migration's economic, political and social effects.

To support a growing research interest in Chinese settlement in British Columbia, the Asian Library at the University of British Columbia (UBC) has cooperated with a number of local institutions to develop a Web site, Historical Chinese Language Materials in British Columbia (HCLMBC): an Electronic Inventory. ${ }^{2}$ The Web site encompasses an online database of records of archival materials, a virtual exhibition of photo and image collections, links to related resources, and listings of relevant organizations. The HCLMBC database is built on the strength of the library's existing archival collections, including a rich body of publications of clan associations from southern Guangdong Province, Mainland China, and the Chinese Times (1914-1992), the longest run of any Chinese newspaper in Canada. The database records are further expanded through partnerships with numerous Chinese Canadian pioneer families, clan and community associations, local and international archives, resource centers, and pertinent individuals. Since the project's inception in 2000 to the end of 2004, the HCLMBC database had included over 13,000 records of archival materials, and the HCLMBC Web site had incorporated more than 500 relevant photos and images. By 
then, the core collection of the database had been established, and the focus of the HCLMBC project moved to digitization of major collections by stages. ${ }^{3}$

During the same period, UBC actively established and promoted a campus-wide initiative, e-Strategy, ${ }^{4}$ which includes e-Learning, e-Research and e-Community, to support the university’s strategic goals in enhancing learning, research, and community through leading-edge technology initiatives. Led by the Office of Learning Technology at UBC, the learning-objects technology was introduced and discussed on campus as part of the e-Learning initiative, through the channels of the $e$-Learning Web site ${ }^{5}$ and a UBC Wiki $^{6}$.

\section{The Pilot Project}

As the focus of the HCLMBC project moved to digitization, the head librarian at the Asian Library was actively seeking a way to integrate the HCLMBC archival collection, including the online database and the online exhibition of photos and images, with university teaching in the subject. The learning-objects technology provided such an outlet and earned her interest and attention.

The head librarian pursued support from a faculty member of the history department at UBC, who was teaching a junior/senior undergraduate course on ChineseCanadian history, to investigate developing a learning-object repository using the archival collection. The faculty member expressed interest in the idea, and the library hired a graduate student from the library school at UBC to work on the pilot project. The project team included the head librarian, the faculty member, the graduate student, and a staff member from the library who managed the HCLMBC project. 
An initial discussion with the faculty member identified student activities associated with the course, which included individual and group study, online discussions, and research projects that would generate products in the form of Web sites. The learning-objects repository would be able to support these activities. As a team, we identified the following project objectives.

- Investigate the topic of learning objects in relation to the archival materials

- Identify materials for inclusion from the HCLMBC archival collection, and develop, if possible, learning objects based on selected materials

- Investigate possible systems to carry, present, and use learning objects

- Create an online prototype highlighting early migration and Chinatowns.

\section{Investigate Learning Objects}

The definition of learning objects has been a much-debated topic since 2000 . IEEE defines them as ${ }^{7}$ "any entity, digital or non-digital, that can be used for learning, education or training.” Wiley (2000) ${ }^{8}$ defines them as “any digital resource that can be reused to support learning.” These definitions are general, and many other researchers, institutions, and learning-object initiatives ${ }^{9}$ have debated their visions. We spent about one month investigating the theories and identified learning objects as pieces of an online tool, such as a tutorial, a diagram, an illustration, a model, an interactive exercise, that has a learning objective, a learning process, and a means of assessment regarding a specific task or a specific piece of knowledge. Within this definitional framework, characteristics of learning objects can include the following.

- Nature: learning objects are digital, and use and distribution of learning objects are in an online environment 
- Purpose: functionally, learning objects are to support distance learning; theoretically, learning objects are building blocks of course content

- Size: a learning object is the smallest entity that contains a single complete meaning to carry out a learning process

- Structure: a learning object usually contains a learning objective, an instructional method, learning content, mechanisms for practice, and a means of assessment

- Creation: creation of learning objects may need expertise from the disciplines of instructional design, computer programming, multimedia design, and library and information science

- Discovery and sharing: learning objects are discoverable, sharable, and assessable through the description of learning-object metadata.

Was there a connection between the archival materials and learning objects? The answer to this question was yes, with concerns. The first concern came from the nature of the materials. Some of the materials were digitized, such as the online exhibition of photos and images, while others were still in their original forms, such as paper, photo, or artifact, with only database records. Digitization of these items would be necessary for these materials to become learning objects.

The second concern arose from the structure of learning objects. The digitized archival materials needed to be sequenced, combined, arranged, and furnished with necessary explanatory text, questions, or exercises to fulfill an explicit learning objective. We agreed that original archival materials can serve as the basis of learning objects, and 
the transformation requires digitization, instructional design, and some computer techniques to integrate digital objects and their appendices.

We also identified well-recognized learning-object metadata schemas, such as Learning-object Metadata ${ }^{10}$ of the Institute of Electrical and Electronics Engineers, Inc. (IEEE) and Learning Resource Meta-data Specification ${ }^{11}$ of the IMS Global Learning Consortium, Inc. (IMS). IEEE's standard is a conceptual model of learning-object metadata schema. IMS's specification is to provide users of IEEE's standard a narrative description of the data model along with guidelines on its use, including the creation of application profiles. ${ }^{12}$ Both the standard and the specification provide mapping to Dublin Core (DC). Canadian Core Learning-object Metadata Application Profile (CanCore) ${ }^{13}$ is one of the application profiles of the IMS specification and provides best practices for creating learning-object metadata in the Canadian educational context.

\section{Select Materials and Develop Learning Objects}

The majority of our materials to develop the prototype site came from the image gallery on the HCLMBC Web site. The online photo and image collections were arranged by donors, such as clan families and museums; and topics, such as Vancouver Chinatowns and Chinese cemeteries. This arrangement helped us choose and place samples into a content model (see Appendix A) which we had developed to reflect the structure of the course and identify learning units. We also included a number of materials which had only archival records in the online database. Digitization of these materials was coordinated by the manager of the HCLMBC project. Meanwhile, we consulted related online resources and visited relevant organizations' Web sites. Then we 
selected a small number of materials which were covered by neither the image gallery nor the archival database to support some categories established in the content model.

By the time we were ready to implement the content model and develop a prototype site, we had more than 50 images covering primarily early migration and Chinatowns, the two areas we wanted to highlight as stated in the project objective. We arranged these materials into the content model according to their temporal coverage and themes represented and collected information about them as completely as possible. This information came from the archival records, accompanying descriptive information, and sometimes the images themselves, which we would use to compose learning-object metadata and construct any possible learning context.

\section{Test Systems}

We initially identified Campus Alberta Repository of Educational Objects (CAREO), ${ }^{14}$ which was readily available and tested at the time on campus as an institutional repository model, to develop our online prototype. Due to the frustrations encountered with CAREO (see Table1), we consulted the Office of Learning Technology about possible alternative systems. We discussed our expectations of system functionalities with the Learning-objects Coordinator and the e-Learning Web Coordinator and demonstrated our content model with samples from the selected set of digital objects. Based on their understanding of our purpose, the coordinators recommended Plone, ${ }^{15}$ an open-source content management software that the office was testing in-house, as an alternative system to develop our prototype site. Our experiences with CAREO and Plone are illustrated and compared in Table 1. 
Table 1. System Comparisons of CAREO and Plone

\begin{tabular}{|c|c|c|}
\hline Categories & CAREO & Plone \\
\hline Nature & $\begin{array}{l}\text { Multidisciplinary learning-object } \\
\text { repository }\end{array}$ & $\begin{array}{l}\text { Open-source content } \\
\text { management system }\end{array}$ \\
\hline $\begin{array}{l}\text { Ability to reflect the } \\
\text { content model (See } \\
\text { Appendix A) }\end{array}$ & $\begin{array}{l}\text { No, display is at an object level, } \\
\text { mixed with objects from other } \\
\text { disciplines }\end{array}$ & $\begin{array}{l}\text { Yes, the system allows } \\
\text { construction of a folder structure } \\
\text { and display is hierarchical }\end{array}$ \\
\hline Media support & Multimedia & Multimedia, but not audio or video \\
\hline Language support & English only & $\begin{array}{l}\text { Multi-language, including } \\
\text { traditional and simplified Chinese }\end{array}$ \\
\hline User authorization & Yes & Yes \\
\hline $\begin{array}{l}\text { Differentiation in user } \\
\text { privileges }\end{array}$ & No & $\begin{array}{l}\text { Yes - member, reviewer, } \\
\text { manager, owner }\end{array}$ \\
\hline $\begin{array}{l}\text { Ability to create } \\
\text { learning-objects on } \\
\text { site }\end{array}$ & $\begin{array}{l}\text { No, learning-objects are created } \\
\text { off site and uploaded to the } \\
\text { repository, although the } \\
\text { "description" field and the } \\
\text { "discuss" function may help } \\
\text { provide auxiliary text to images }\end{array}$ & $\begin{array}{l}\text { No, learning-objects are created } \\
\text { off site and uploaded to the } \\
\text { system, although system supports } \\
\text { creation of Web pages and the } \\
\text { "description" field and the "add } \\
\text { comment" function may help } \\
\text { provide auxiliary text to images }\end{array}$ \\
\hline Metadata & $\begin{array}{l}\text { Fixed metadata template } \\
\text { according to CANCORE } \\
\text { guidelines; comprehensive }\end{array}$ & $\begin{array}{l}\text { Fixed metadata template } \\
\text { generated by the system, } \\
\text { including of Title, Description, } \\
\text { Keywords, Effective/Expiration } \\
\text { Date, Format, Language, } \\
\text { Copyrights and Contributors; } \\
\text { simple }\end{array}$ \\
\hline
\end{tabular}




\begin{tabular}{|c|c|c|}
\hline $\begin{array}{l}\text { Ability to support } \\
\text { individual study }\end{array}$ & $\begin{array}{l}\text { Yes, objects can be viewed online } \\
\text { on an individual basis }\end{array}$ & $\begin{array}{l}\text { Yes, objects can be viewed online } \\
\text { on an individual basis }\end{array}$ \\
\hline $\begin{array}{l}\text { Ability to support group } \\
\text { study }\end{array}$ & $\begin{array}{l}\text { Yes, objects can be viewed online } \\
\text { in a group setting }\end{array}$ & $\begin{array}{l}\text { Yes, objects can be viewed online } \\
\text { in a group setting }\end{array}$ \\
\hline $\begin{array}{l}\text { Ability to support } \\
\text { online discussions }\end{array}$ & $\begin{array}{l}\text { Yes, the repository provides } \\
\text { "discuss" function at an object } \\
\text { level }\end{array}$ & $\begin{array}{l}\text { Yes, the system provides "add } \\
\text { comment" function at an object } \\
\text { level; the system also supports } \\
\text { establishment and activities of } \\
\text { "discussion forums" }\end{array}$ \\
\hline $\begin{array}{l}\text { Other support for user } \\
\text { interactions }\end{array}$ & None & $\begin{array}{l}\text { Establishment of online member } \\
\text { profiles helps members to know } \\
\text { each other better; ability to search } \\
\text { members; ability to create } \\
\text { member home pages; ability to } \\
\text { "share" and "syndicate" resources }\end{array}$ \\
\hline $\begin{array}{l}\text { Ability to download } \\
\text { objects }\end{array}$ & $\begin{array}{l}\text { Not intuitive, although images can } \\
\text { be "copy" and "paste" }\end{array}$ & $\begin{array}{l}\text { Not intuitive, although images can } \\
\text { be copied and pasted }\end{array}$ \\
\hline $\begin{array}{l}\text { Ability to submit and } \\
\text { review objects }\end{array}$ & No & Yes \\
\hline $\begin{array}{l}\text { Ability to set object } \\
\text { status }\end{array}$ & No & $\begin{array}{l}\text { Yes - "make private", "visible", } \\
\text { "submit", "publish" }\end{array}$ \\
\hline System stability & $\begin{array}{l}\text { Questionable - frequently down } \\
\text { on a daily basis during testing }\end{array}$ & $\begin{array}{l}\text { Good - no down time experienced } \\
\text { during testing }\end{array}$ \\
\hline
\end{tabular}


Through testing, we concluded a learning-object system should provide the following functionalities.

- Support for display and integration of multiple media formats

- Ability to organize objects into logical structures

- Mechanisms to design and modify a metadata template

- Methods of submitting, reviewing and using objects

- Various ways of online user interactions.

These criteria will be valuable for us to evaluate learning-object systems when relevant technology becomes more mature.

\section{Create Prototype}

The e-Learning Web Coordinator helped us create a prototype site using the Plone software (also see Appendix B). ${ }^{16}$ The coordinator localized the software to reflect our project purpose and set up a site-manager account. We copied the initial set of selected images on a CD-ROM, and the coordinator batch loaded them to the site. With the sitemanager account, we further added metadata to the initial set of images, perfected the site structure, and complemented the site with additional images and resources. At a final stage of the prototype, we had 102 images covering most of the categories established in the content model (see Appendix A) and added a list of educational video resources available at UBC libraries that would support study of the course (see Appendix B).

\section{Conclusion}

The pilot project generated positive impact in a number of ways. It gained us valuable knowledge on the learning-objects theory and experience with developing a learning-object repository. It demonstrated the library's commitment to enhancing 
university students' learning resources and increased the library's visibility in the university's technology initiative. The online repository brings immediate, central access of archival materials to students from remote and diffused locations. The faculty member was excited to incorporate this innovative online tool into his teaching and was ready to become manager of the prototype site so he could further contribute materials and manipulate them to fit the context and learning objectives of his course. The prototype site was an initial step showing how library resources could integrate with faculty teaching in an online environment. Based on the experience with the prototype, the head librarian was interested in enlarging the attempt to work with other faculty members in the history department and developing a research repository of a larger scope to support the study of overall Asian immigrant history and migration in North America. A plan for expansion based on the prototype was to extend material formats to digitized versions of oral history and educational videos. Moreover, demonstration of the prototype site during the head librarian's visit to Mainland China attracted further contribution of archival materials to the HCLMBC collection from local libraries, archives, and museums. This demonstrated the pilot project's impact on increasing the archival collection's visibility and generating broader interest to enrich its research value.

The pilot project suggests that libraries should take a proactive role in their institutions' information and learning technology initiatives, and make use of library resources in a more dynamic and timely manner. From it, we learned that it is beneficial to communicate with teaching faculty to explore ways of creative use of library resources. In addition, information technology units on campus are quality resources to rely on to resolve technological issues and obtain relevant advice. 
The next steps of the pilot would be to evaluate the prototype based on faculty and student experiences, to enhance the initial set of digital objects based on the definitional framework of learning objects, and to promote this endeavor to a larger audience if broader partnerships are to be sought. 


\section{Footnotes}

1. http://www.sfu.ca/davidlamcentre/hclmbc/introduction.html

2. http://www.sfu.ca/davidlamcentre/hclmbc/index.html

3. http://www.sfu.ca/davidlamcentre/hclmbc/introduction.html

4. http://www.e-strategy.ubc.ca/Homelink.html

5. https://www.elearning.ubc.ca/home/index.cfm

6. http://careo.elearning.ubc.ca/cgi-bin/wiki.pl?FindLearningObjects

7. http://ieeeltsc.org/wg12LOM/lomDescription

8. http://opencontent.org/docs/dissertation.pdf

9. http://www.wisc-online.com/Info/FIPSE\%20\%20What\%20is\%20a\%20Learning\%20Object.htm; http://learnet.hku.hk/objects.htm; http://www.fastrakconsulting.co.uk/tactix/features/objects/objects.htm

10. http://ltsc.ieee.org/wg12/files/LOM_1484_12_1_v1_Final_Draft.pdf

11. http://www.imsglobal.org/metadata/index.html

12. http://www.imsglobal.org/ap/apv1p0/imsap_oviewv1p0.html

13. http://www.cancore.ca/en/

14. http://www.careo.org/

15. http://plone.org/

16. http://142.103.172.228:8080/chicanhistory 


\section{Additional Reading}

Campus Alberta Repository of Educational Objects. 2002. http://www.careo.org/

CanCore Metadata Initiative. CanCore. (2004). http://www.cancore.ca/en/index.html

Chinese Canadian History: Primary Resources. 2003.

http://142.103.172.228:8080/chicanhistory

Historical Chinese Language Materials in British Columbia (HCLMBC): an Electronic Inventory. (2000). http://www.sfu.ca/davidlamcentre/hclmbc/index.html

IMS Global Learning Consortium, Inc. IMS Application Profile Guidelines Overview. 2005. http://www.imsglobal.org/ap/apv1p0/imsap_oviewv1p0.html

IMS Global Learning Consortium, Inc. IMS Learning Resource Meta-data Specification. 2004. http://www.imsglobal.org/metadata/index.html

Learning Technology Standards Committee, Institute of Electrical and Electronics Engineers, Inc. Learning-object Metadata Standard. (2005). http://ieeeltsc.org/wg12LOM/lomDescription

Learning Technology Standards Committee, Institute of Electrical and Electronics Engineers, Inc. Draft Standard for Learning-object Metadata. 2002. http://ltsc.ieee.org/wg12/files/LOM_1484_12_1_v1_Final_Draft.pdf

Office of Learning Technology, University of British Columbia. UBC Wiki: Find Learning-objects. 2001. http://careo.elearning.ubc.ca/cgibin/wiki.pl?FindLearningObjects

Plone Foundation, et al. Plone: A user-friendly and powerful open source Content Management System. 2000. http://plone.org/ 
Shepherd, Clive. “Objects of Interest.” IT Training (February 2001). http://www.fastrakconsulting.co.uk/tactix/features/objects/objects.htm

University of British Columbia. e-Learning at UBC. (2003).

https://www.elearning.ubc.ca/home/index.cfm

University of British Columbia. UBC's e-Strategy. (2003). http://www.estrategy.ubc.ca/Homelink.html

University of Hong Kong. LEARNet: Learning-objects. (2005?).

http://learnet.hku.hk/objects.htm

Wiley, David A. Learning-object Design and Sequencing Theory. 2000. http://opencontent.org/docs/dissertation.pdf

Wisconsin Online Resource Center (Wisc-Online). What are Learning-objects. (2005). http://www.wisc-online.com/Info/FIPSE\%20-

\%20What\%20is\%20a\%20Learning\%20Object.htm 


\section{Appendix A}

\section{CONTENT MODEL}

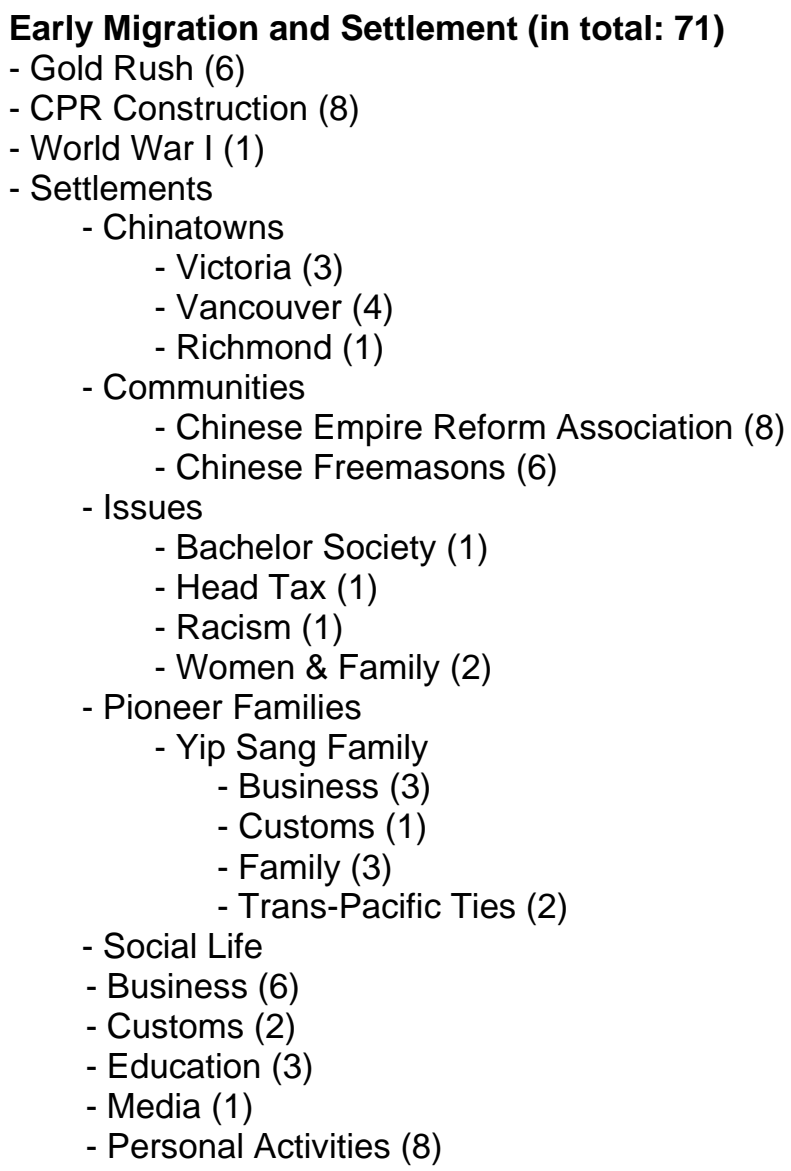

\section{Exclusion Period and Wartime (in total: 21)}

- Exclusion Act (0)

- Japanese Invasion - World War II

- Events (1)

- Historical Sites (1)

- Profiles

- Men

- Cedric Mah (3)

- Force 136 (2)

- Other Distinguished (1)

- Women (3)

- Trans-Pacific Ties (4)

- Settlements

- Chinatowns

- Richmond (2)

- Communities (1)

- Social Life

- Business (2)

- Education (1)

Post-War and the Recent (in total: 10) 
- Vancouver Centralization

- Vancouver (1)

- Richmond (4)

- Steady Growth (0)

- New Immigrants

- Settlements

- Richmond (4)

- Trans-Pacific Ties (1) 


\section{Appendix B}

\section{SCREEN CAPTURES OF THE PROTOTYPE SITE AT PLONE}

\section{Figure 1. Chinese Canadian History Learning-object Repository Prototype: Home Page}

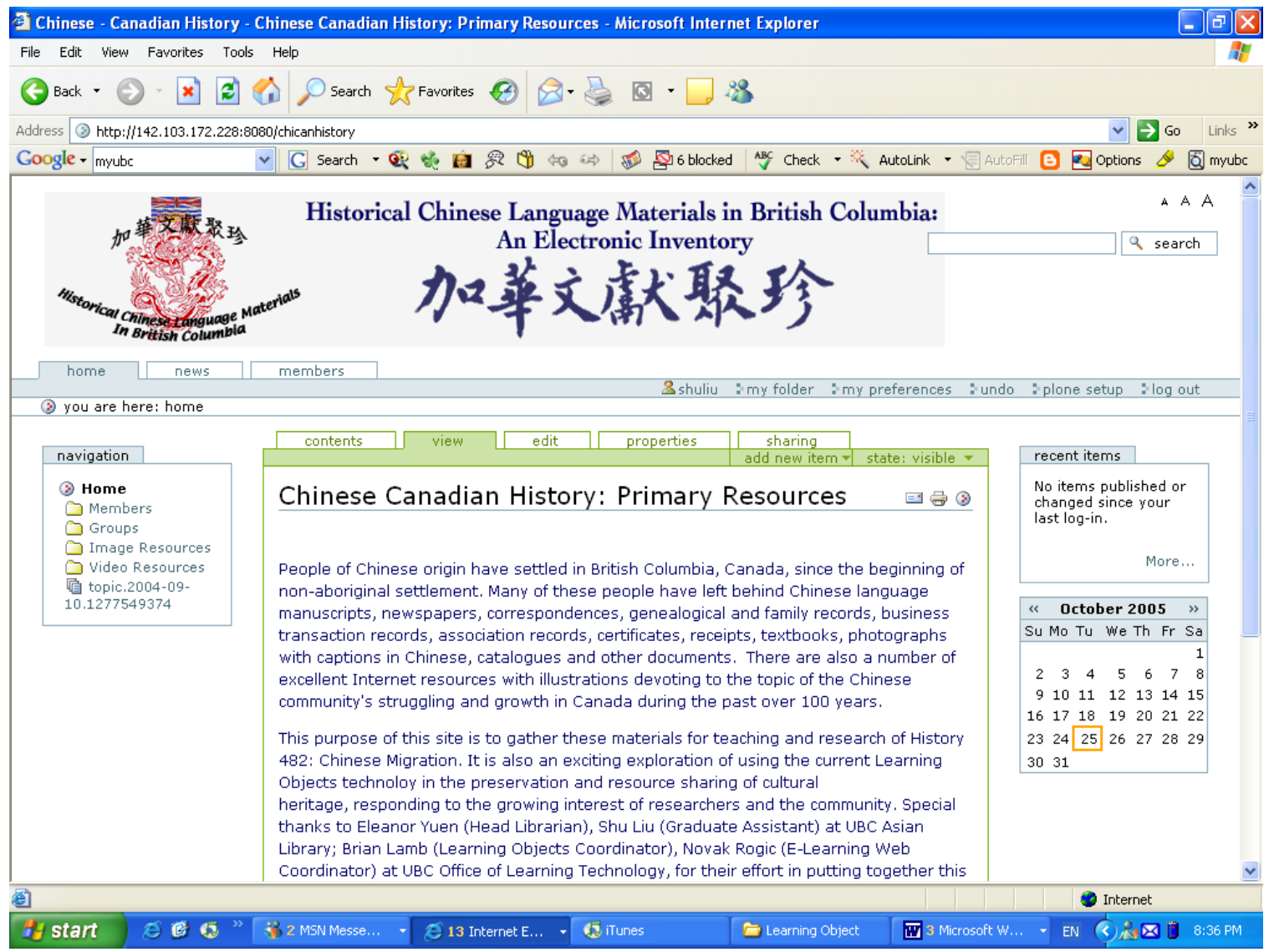

Screen capture courtesy of Eleanor Yuen and the pilot Learning Object Project at the Asian Library of the University of British Columbia. 


\section{Figure 2. Chinese Canadian History Learning-object Repository Prototype: Hierarchical Display Sample I}

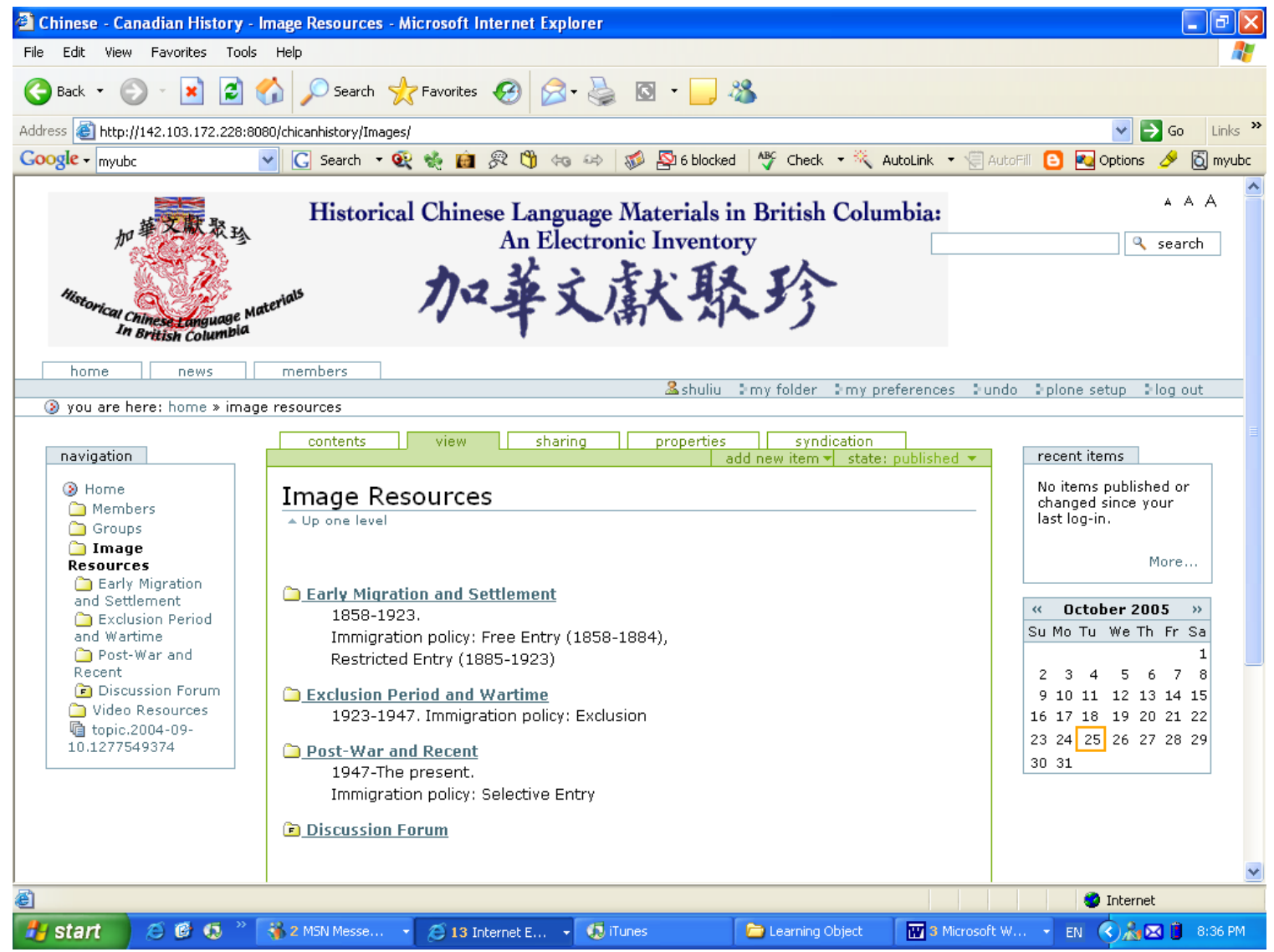

Screen capture courtesy of Eleanor Yuen and the pilot Learning Object Project at the Asian Library of the University of British Columbia. 


\section{Figure 3. Chinese Canadian History Learning-object Repository Prototype: Hierarchical Display Sample II}

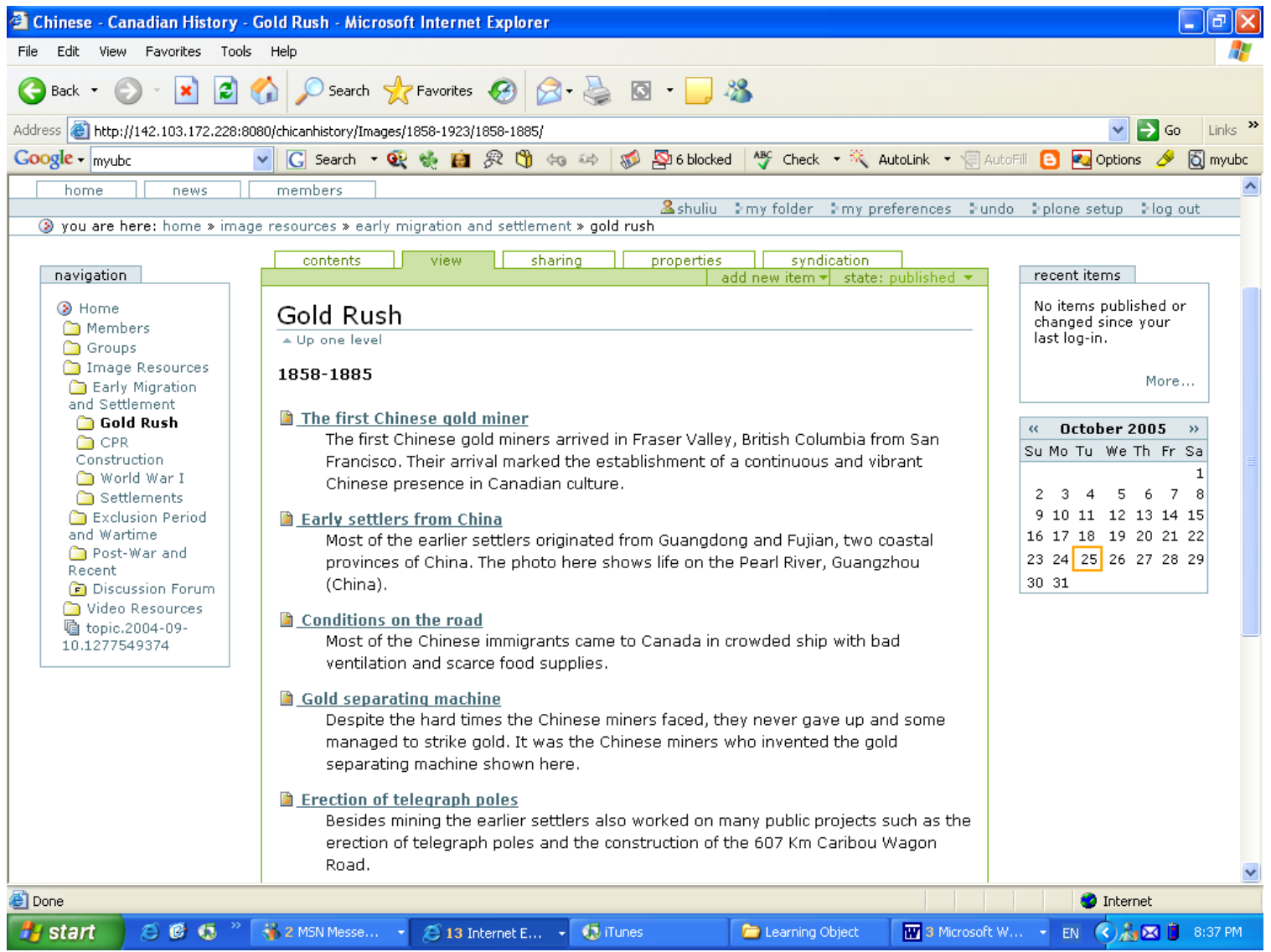

Screen capture courtesy of Eleanor Yuen and the pilot Learning Object Project at the Asian Library of the University of British Columbia. 


\section{Figure 4. Chinese Canadian History Learning-object Repository Prototype: Object-level Display Sample}

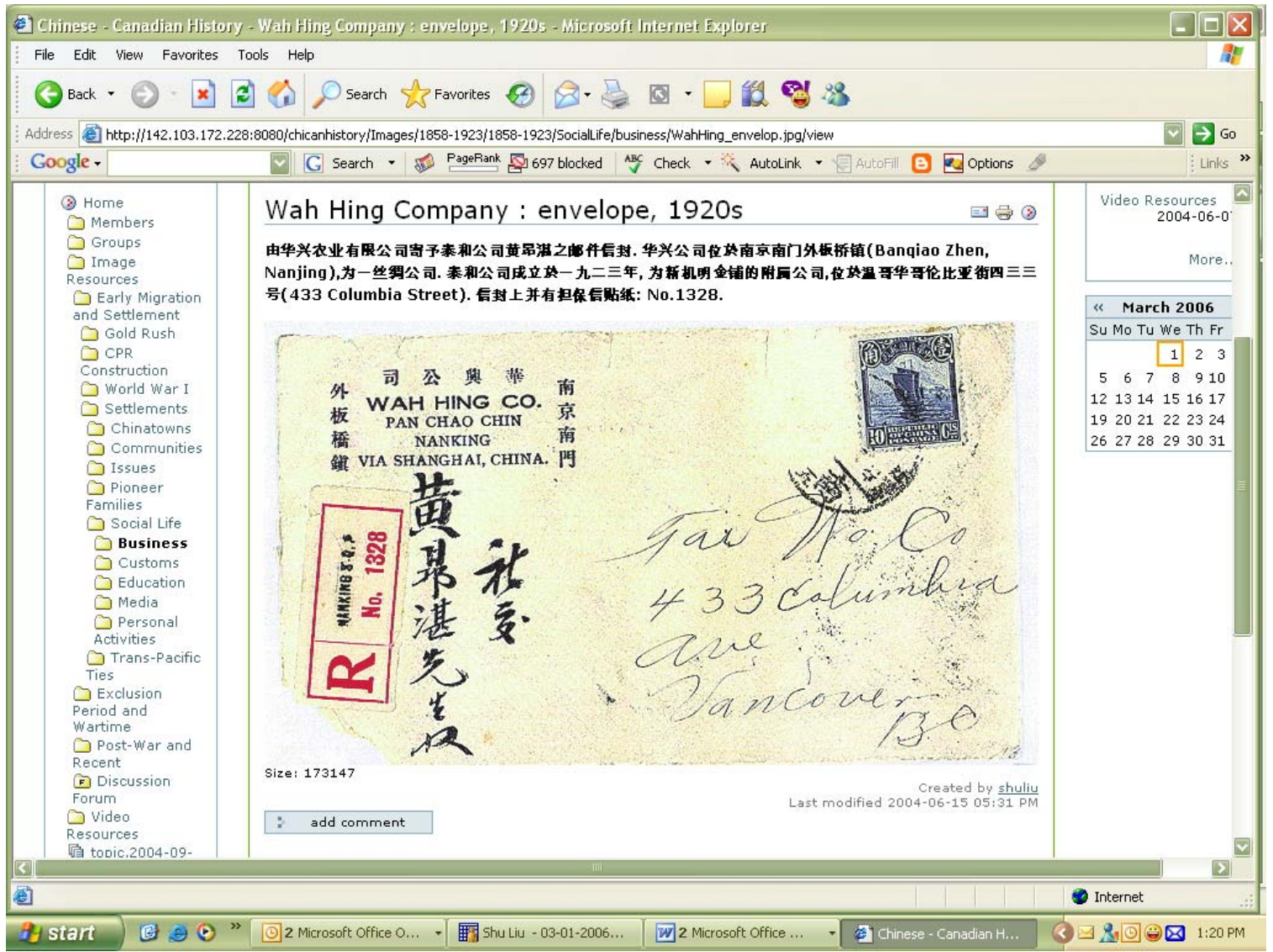

Screen capture courtesy of Eleanor Yuen and the pilot Learning Object Project at the Asian Library of the University of British Columbia. 


\section{Figure 5. Chinese Canadian History Learning-object Repository Prototype: Video Resources}

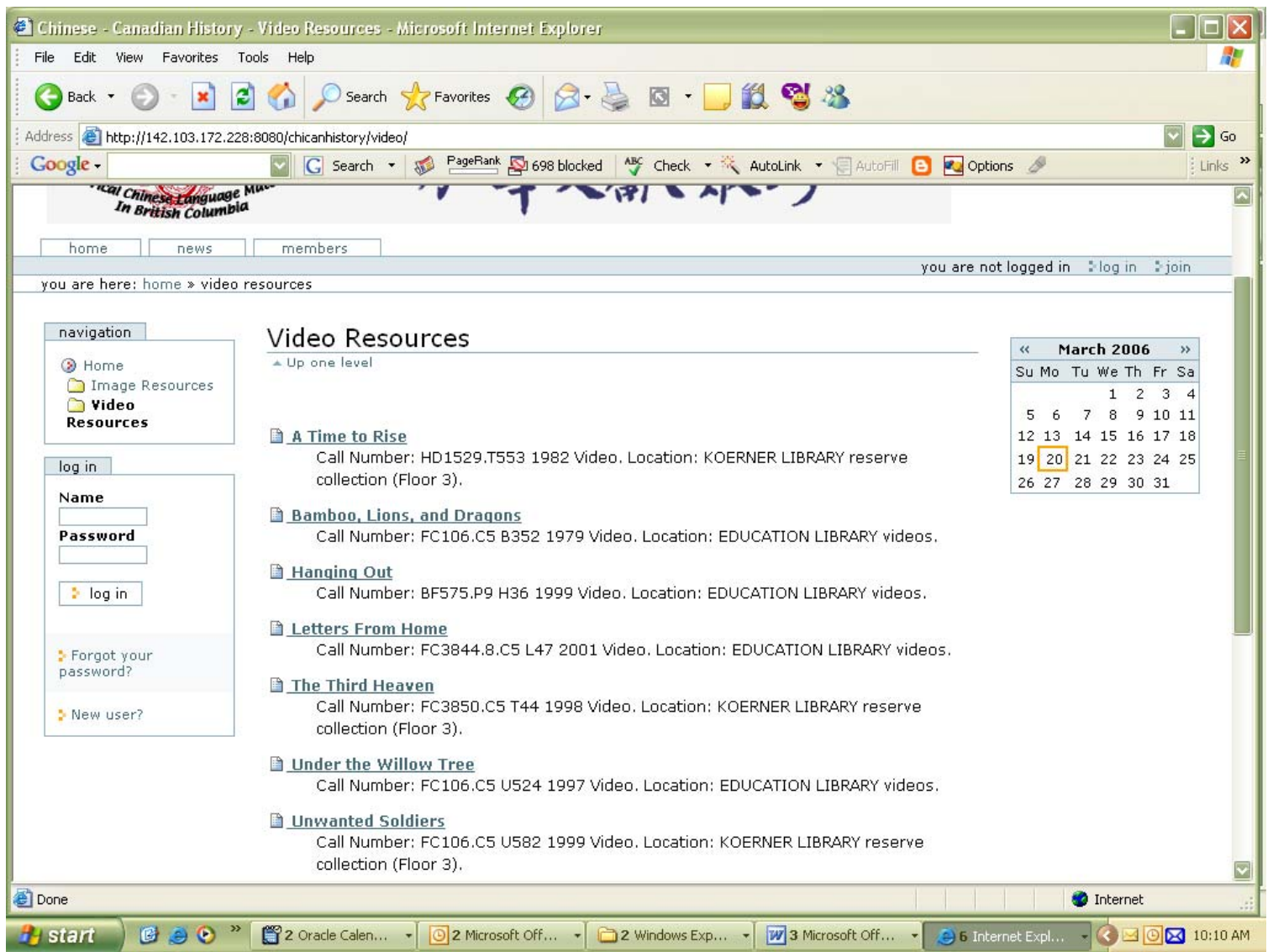

Screen capture courtesy of Eleanor Yuen and the pilot Learning Object Project at the Asian Library of the University of British Columbia. 